\title{
European Project in Danger? Understanding Precisely the Phenomena "Euroscepticsm, Populism and Extremism" in Times of Crisis
}

\author{
Florian Hartleb ${ }^{1}$ \\ ${ }^{1}$ Jean-Monnet-Chair for European Politics, University of Passau, Passau, Germany \\ Correspondence: Florian Hartleb, Jean-Monnet-Chair for European Politcs, University of Passau, \\ Dr.-Hans-Kapfinger-Street 14, 94032 Passau, Germany, Tel: 49-851-509-2989. E-mail: florian_hartleb@web.de
}

Received: August 27, 2012 Accepted: September 27, 2012 Online Published: September 28, 2012

doi:10.5539/res.v4n5p45 URL: http://dx.doi.org/10.5539/res.v4n5p45

\begin{abstract}
The European project has recently reached a critical point, where a discussion on the fundamental objectives of the European Union has entered public debate. Obviously, a new euroscepticism is on the rise which is often linked with the agenda of populist or even extremist parties and a general tendency of 'renationalizing Europe'. The drifting apart within the mainstream parties shows the cracks in European society. The success of right-wing populist tends to be volatile despite of the fact that this heterogeneous party family seems to be a permanent factor in the European party landscape. In Austria or France, the parties show with the second generation of leadership that they are able to renew themselves. But the parties differ a lot in the national backgrounds, can be extremist or totally not. In general, it is unlikely that any right-wing populist or extremist international groups will be formed any time soon competing as unified force at the European level. Extremist parties do not have enough potential support to pose a threat to the existing liberal democratic order with some exceptions such as Hungary an Greece due to the time of a severe crisis not only in economic terms. The power of European integration is so strong that it is unlikely that there will be any national U-turns on this issue, despite the occasional upsurge of populism or extremism in individual countries. Nevertheless, the debate over the future of European integration and of the European Union itself will continue to have a significant influence on the political debate in individual member states.
\end{abstract}

Keywords: political parties, populism, extremism, populism, eurocrisis, renationalisation

\section{The New Euroscepticism and Its Relevance}

The European project has recently reached a critical point, where a discussion on the fundamental objectives of the European Union has entered public debate. In fact, two of the greatest achievements of European unity are in serious peril these days: in Greece and other EU countries there is a fight for the survival of the single currency, the euro; and in Denmark, the authorities have begun to carry out passport checks at land borders, in defiance of the Schengen agreement. Obviously, the current problems confronting the integrity of the EU are not confined to the domain of economics; the Union is also threatened by a political and perhaps even a cultural crisis.

Currently there are considerable concerns about a new Euroscepticism arising in response to recent developments and a general feeling of malaise towards the European project from both national elites and ordinary citizens of Member States. Observers speak about an anti-European virus spreading via a new wave of street protests, especially in Greece and Spain, and among unsatisfied people in general. Even in Germany, the driving force of Europe, the EU is seen as a problem rather than a solution. The reason is rather obvious: some countries of the eurozone are in serious financial distress. For instance, the EU has had to create a European bailout fund for states, such as Greece, Ireland, Portugal and maybe even Italy, that have suffered grave financial problems as a collateral consequence of the financial crisis of 2008. These measures of solidarity, paid for by the financially stronger countries, and the entire construct of the common economic zone with its flagship currency, the euro, are difficult to justify to the populations of the rich, subsidising countries. As a result, European elites are talking of a renewed danger of Euroscepticism. My aim in this paper is to discuss this phenomenon comprehensively, since it is important to distinguish between Euroscepticism as a general mood and Euroscepticism as (part of) a particular political and ideological profile presented by specific parties.

For some time now disillusionment has been spreading throughout the Member States. As a 2006 Eurobarometer report (Eurobarometer, 2006) determined, only 49\% (not even half) of the population welcomes the membership 
of their respective countries in the EU. This number fluctuates significantly, however, especially among the new Member States, and for obvious reasons depends on the particular definition of Euroscepticism employed. The general trend across Member States is hard to describe because of the differences among them. In spring 2010, many people in Slovenia (71\%) and Bulgaria (65\%) trusted the EU, while only a few people did in Germany $(36 \%)$ and the UK $(20 \%)$. (Note 1) The following indicators could herald the dawning of a new era of renationalisation:

- The unpopularity of the European project as a result of the current euro crisis;

-The growth in popularity of populist, nationalist movements, at least in some places;

-The possible formation of an "international" group within the European Parliament, with networking aspects;

-The revival to some extent of the notion of the nation state in the form of protectionism.

This article therefore engages with the keyword 'Euroscepticism', which is somehow connected with both populism and extremism. (Note 2) The distinction between these two phenomena involves the 'insider' role of populists and the 'outsider' role of extremists, as related to liberal democracy. The connection to Euroscepticism does not mean that populists have anti-liberal features and goals that are a threat to immigrants, minorities and so on. Populism should not be discredited as unconstitutional from the outset. It does not undermine the cornerstones of the democratic canon of values. Populist 'anti' attitudes stem from a kind of goal-oriented opportunism, not from a systemic opposition. An anti-system party refuses to cooperate with the 'system' parties and has an agenda of destructive refusal within the political process; an anti-party party desires to integrate into the political process constructively, in its own way, and its fundamental traits include always being prepared to communicate and form coalitions. Populist parties operate not with anti-system feelings, but with anti-party feelings.

This article will develop on the basis of Hartleb (2011) the following five hypotheses:

1. Despite many opportunities, Euroscepticism is not expressed through a common European-wide project. Recently, for example, the Libertas party failed in the 2009 European elections.

2. Euroscepticism can be linked with right-wing populism and extremism, but is also expressed within established parties and the left in terms of populism and extremism.

3. Euroscepticism can be expressed without any extremist or populist background.

4. The success of Euroscepticism is highly variable, as the example of Poland after its EU accession demonstrates.

In what follows, I will first discuss whether and how 'Euroscepticism' can be classified. The continuing European integration and institutional strengthening of political parties through the Lisbon Treaty may have led Europeanised parties and coalitions in the European Parliament to form a Eurosceptical alliance. I then take a close look at Euroscepticism in Western and Eastern Europe, considering the diverse motives for this phenomenon. It seems that in Western Europe, Eurosceptical and right-wing activities go hand in hand, a fact that suggests the need for new research. It may also be plausible to interpret strong Euroscepticism as an important characteristic of a pan-European right-wing extremism. The next section specifically analyses Eastern Central Europe. A 'post-EU-accession syndrome' may have advanced the development of a regional Eurosceptical family of parties in the Visegrád states especially.

\section{The Meaning of the Term 'Euroscepticism'}

Euroscepticism should not automatically be classified as a right-wing response. But classically right-wing extremist or novel right-wing populist formations will tend towards Euroscepticism (arguing for 'preservation of the nation state'), as will many post-Socialist ones (in their slogan, 'a different, more social Europe'). Euroscepticism is a comprehensive term, comprising a whole spectrum of positions regarding political content. Not surprisingly, its origins lie in traditionally Eurosceptical Great Britain, where it entered into political and journalistic jargon in the middle of the 1980s. The term became widespread with the debates over the Maastricht Treaty, which shifted the 'permissive consensus' that had prevailed so far to an open debate about the benefits and costs of further integration.

The Oxford English Dictionary then defined a 'Eurosceptic' as someone not very enthused by the increased power of the European Community or Union. In this early usage period, the term designated an opposition towards both the EC/EU and towards European integration as a whole (Harmsen \& Spiering 2004, 15-17). Numerous authors who were dissatisfied with the term 'Euroscepticism' proposed alternatives to describe the 
phenomenon: 'Euro-indifference', 'Europhobia', 'Eurorealism', ‘critical Europeans' or 'Eurocynicism' (see Crespy \& Verschueren 2009, 382).

Indeed, the positions towards Europe as a whole and towards the EU in particular are very different, as Chris Flood (2002) illustrates:

Table 1. Categories of EU alignments (regarding the EU in general or some specified aspect(s) of it)

\begin{tabular}{lc}
\hline Category & Position \\
\hline Maximalist & $\begin{array}{c}\text { Pushing integration as far and as fast as is feasible towards the practical realisation of a chosen } \\
\text { model }\end{array}$ \\
Reformist & $\begin{array}{r}\text { Endorsing the advance of integration, subject to remedying deficiencies in what has already been } \\
\text { achieved }\end{array}$ \\
$\begin{array}{c}\text { Gradualist } \\
\text { Minimalist }\end{array}$ & Accepting some advance of integration, as long as it is slow and piecemeal \\
Revisionist & Accepting the status quo, but wanting to limit further integration, as far as possible \\
Rejectionist & Wanting to return to an earlier state, usually before a treaty revision \\
Outright refusal of integration, coupled with opposition to participation
\end{tabular}

In 1998, British political scientist Paul Taggart characterised Euroscepticism as a 'touchstone of dissent' within Western European political party systems (Taggart, 1998). According to my own observations I would emphasise the following: in the political debates concerning the future of Europe since then, the distinction between European integration and the European Union has often been blurred, despite the fact that these don't necessarily go hand in hand. European identity is possible even when an EU identity related to the institutions is not. Many politicians mix the terms while pointing out a deeper integration. This might explain the broad acceptance of the phenomenological distinction between 'hard' and 'soft' Euroscepticism made by Paul Taggart and Aleks Szczerbiak regarding the 2004 Eastern European candidates for accession to the EU (Taggart \& Szczerbiak, 2004; Szczerbiak \& Taggart, 2008):

1. Hard Euroscepticism is where there is a basic opposition to the EU and European integration and therefore can be seen in parties who think that their countries should withdraw from membership, or whose policies towards the EU are tantamount to being opposed to the whole project of European integration as it is currently conceived.

2. Soft Euroscepticism is where there is not a basic objection to European integration or EU membership but where concerns on one (or a number) of policy areas lead to the expression of qualified opposition to the EU, or where there is a sense that 'national interest' is currently at odds with the EU's trajectory.

The 'soft' version implies the qualified rejection of certain aspects of the integration project or of the EU in its current institutional form. A common argument is that national interests run counter to the supranational agreements. The 'hard' form of Euroscepticism, on the other hand, rejects the 'idea of Europe' fundamentally and therefore also accession to or membership in the EU (Taggart \& Szczerbiak, 2004; Szczerbiak \& Taggart, 2008). From the perspective of democracy theory and integration policy, the hard Eurosceptics are seen as problematic, as they hardly seek or effect any positive development of the integration process (Weßels, 2009). A whole range of parties across Europe can be labelled as 'Eurosceptic'. In 2002 Taggart and Szczerbiak counted 72 parties across the political spectrum in the Member States and 34 in those countries then being considered as candidates for membership. This included all marginal, non-established small parties (Taggart \& Szczerbiak, 2008b). Many of these forces still exist, and other new forces such as the True Finns have gained a significant entry into the European party landscape. From a purely quantitative standpoint, the number of Eurosceptical parties would suffice to constitute a party family on its own.

\section{Euroscepticism in Western Europe: Exclusive to Right-Wing Populist Parties?}

In theory Euroscepticism can be expressed by all political camps and even by political elites. The political culture of individual countries is relevant here. Countries such as Great Britain and Austria are traditionally Eurosceptical, as is shown by polls. The political discourse of the elites is significantly influenced by this phenomenon. In addition, the populist logic of 'us versus the governing class' serves well the purpose of arguing against the EU. Right-wing populism is a primary characteristic, whereas Euroscepticism is at most a secondary characteristic. Many right-wing populist formations even need Europe when addressing the question of barriers against immigration. But some of these forces may regard the migration topic differently, or argue that the internationalist elite in Brussels wants to let in too many immigrants. 
Table 2. Pure Eurosceptical forces (without a right-wing populist agenda)

\begin{tabular}{|c|c|c|c|c|c|}
\hline \multirow[b]{2}{*}{ Country } & & \multirow[b]{2}{*}{ Political party } & \multicolumn{2}{|c|}{ Latest national elections } & \multirow{2}{*}{$\begin{array}{c}\text { European } \\
\text { elections } 2009 \\
\text { Results }^{2}\end{array}$} \\
\hline & & & Date & Results $^{1}$ & \\
\hline EU-wide & A & Libertas & & & $\begin{array}{c}1 \text { seat in France } \\
\text { only }\end{array}$ \\
\hline Great Britain & Dis & Conservative and Unionist Party & $06 / 05 / 2010$ & $36.1 \%$ & $27.0 \%$ \\
\hline Great Britain & DIs & $\begin{array}{l}\text { United Kingdom Independence Party } \\
\text { (UKIP) }\end{array}$ & $06 / 05 / 2010$ & $3.1 \%$ & $16.5 \%$ \\
\hline
\end{tabular}

Sources: ${ }^{1}$ http://www.parties-and-elections.de, accessed 13 May $2011 ;{ }^{2}$ European Parliament

Table 3. Success of right-wing populist parties in Western Europe (according to the latest national election results)

\begin{tabular}{|c|c|c|c|c|}
\hline \multirow[b]{2}{*}{ Country } & \multirow[b]{2}{*}{ Political party } & \multicolumn{2}{|c|}{$\begin{array}{l}\text { Latest national } \\
\text { elections }\end{array}$} & \multirow{2}{*}{$\begin{array}{c}\text { European } \\
\text { elections } 2009 \\
\text { Results }^{2}\end{array}$} \\
\hline & & Date & Results $^{1}$ & \\
\hline Norway & Progress Party (Fremskrittspartiet - FRP) & $14 / 09 / 2009$ & $22.9 \%$ & - \\
\hline Finland & The Finns (Perussuomalaiset - PS) & $17 / 04 / 2011$ & $19.0 \%$ & $9.8 \%$ \\
\hline Austria & $\begin{array}{l}\text { Freedom Party of Austria (Freiheitliche Partei } \\
\text { Österreichs - FPÖ) }\end{array}$ & $28 / 09 / 2008$ & $17.5 \%$ & $12.71 \%$ \\
\hline France & National Front (Front National - FN) & $10 / 06 / 2012$ & $13.6 \%$ & $6.3 \%$ \\
\hline Denmark & Danish People's Party (Dansk Folkeparti - DF) & $15 / 09 / 2011$ & $12.3 \%$ & $14.8 \%$ \\
\hline Austria & $\begin{array}{l}\text { Alliance for the Future of Austria (Bündnis } \\
\text { Zukunft Österreich - BZÖ) }\end{array}$ & $28 / 09 / 2008$ & $10.7 \%$ & $4.58 \%$ \\
\hline $\begin{array}{l}\text { The } \\
\text { Netherlands }\end{array}$ & Freedom Party (Partij voor de Vrijheid - PVV) & $12 / 09 / 2012$ & $10.1 \%$ & $16.97 \%$ \\
\hline Italy & Northern League (Lega Nord - LN) & $14 / 04 / 2008$ & $8.3 \%$ & $10.2 \%$ \\
\hline Belgium & Flemish Interest (Vlaams Belang - VB) & $13 / 06 / 2010$ & $7.7 \%$ & $9.85 \%$ \\
\hline Sweden & $\begin{array}{l}\text { Sweden Democrats (Sverigedemokraterna } \\
\text { SD) }\end{array}$ & $19 / 09 / 2010$ & $5.7 \%$ & $3.27 \%$ \\
\hline
\end{tabular}

Sources: ${ }^{1}$ http://www.parties-and-elections.de, accessed 13 May $2011 ;{ }^{2}$ European Parliament.

Euroscepticism plays a special role within the party system in the UK, which has a specific Eurosceptical political culture. The British are particularly concerned about what they regard as a tendency of the EU to move in the direction of what is often described in the British media as the 'United States of Europe'. Britain has decided to opt out of the eurozone on the basis that a persistent majority of the British public and the political elite regard it as a significant example of the move towards an integrated superstate. British Euroscepticism also bears the imprint of Britain's distinctive historical and geopolitical experiences: the construction of an 'imagined community' in the form of the special Anglo-Saxon relationship with the US and the fear of a perfidious Franco-German conspiracy threatening British national interests; the fear of losing the Westminster tradition of (national) parliamentary sovereignty and independence; and its long history of independence, liberty and democratic evolution.

Therefore, Euroscepticism has a serious impact on the whole British party system. The traditional Conservatives 
('Tories') now in government could be considered Eurosceptical towards the EU in many ways, but without having a right-wing, anti-elitist agenda in general. Though it was the Conservative Party that took the UK into the EU (then the European Communities), many Conservatives subsequently became hostile to the EU. One of the earliest groups formed to specifically oppose UK involvement in Europe was the Anti-Common Market League, initially based in the Conservative Party. Margaret Thatcher's antipathy towards deepening European integration became more pronounced during her years as prime minister, particularly after her third election victory in 1987. She had the idea that the role of the EC should be limited to ensuring free trade and effective competition, and feared that the EC's approach was at odds with her views on smaller government and deregulation. Thatcher remained in favour of an intergovernmental and free trade Europe (Thatcher, 1993), with limited cooperation between essentially independent states. Ironically, Thatcher wrote: 'That such an unnecessary and irrational project as building a European superstate was ever embarked upon will seem in future years to be perhaps the greatest folly of the modern era' (Thatcher, 2002). The current Conservative leader and prime minister, David Cameron, belongs to the Eurosceptic wing of his party and is reluctant to support the deepening of the European integration process.

Another force in the UK deserves attention: a purely Eurosceptical party, the United Kingdom Independence Party (UKIP), holds withdrawal from EU as its main policy. In the 2009 European elections, the UKIP came second in the UK, beating the then-governing Labour Party, with its share of the vote increasing by $0.4 \%$ to a total of $16.5 \%$. But neither the Tories nor the UKIP belong to the so-called right-wing populist family. There is no populist logic, or even the expression of a British tradition, behind the fear of a superstate EU.

Since the early 1980s, parties of a new type more often than not right-wing populists with an anti-establishment ethos, a protest and taboo-breaking agenda, and a charismatic leader have repeatedly performed well in national elections within some Western European countries (Mudde, 2007). Populism refers specifically to anti-elitism, pragmatism and a politics based on prejudices, but not to an anti-constitutional stance. The common features of populism are

- an anti-elitist discourse ('us' against the establishment)

- a politics of stereotypes

- not anti-constitutional or anti-democratic

- no nostalgia for fascism or the extremist past in general

- $\quad$ protest topics (negative and cynical formulations; negative campaigning)

- a charismatic leader

- no fixed dogmatic ideology, flexible topics (chameleon-like)

In addition, there are two central aspects for understanding the logic of populism:

- The vertical dimension, as a general characteristic of populism: a separation from established political institutions and traditional parties; an attitude of 'us' against 'those above'.

- The horizontal dimension, as a specific right-wing variant of populism: a separation from immigrants, foreigners and criminals; an attitude of 'us' against 'those from outside'.

As applied to Euroscepticism, the vertical can be expressed as 'us against the bureaucrats' and in the horizontal dimension as 'us against the immigrant- or foreigner-welcoming policy of the EU'.

As one example of a right-wing populist, the Netherlands' Geert Wilders is, despite his anti-Islamism, not blatantly racist, and is pro-Israel and pro-US. He plays the democratic game and supports the current government. Similar challengers have appeared on the scene since the last elections in Sweden and in Finland. Other existing right-wing populist parties are showing the ability to reinvent themselves. In Austria, Heinz-Christian Strache has replaced Jörg Haider at the helm of the Freedom Party of Austria (FPÖ), and in France, Marine Le Pen has taken the place of her father as the leader of the Front National. Despite having far-right roots, the Swedish Democrats have managed to adopt a more accessible, moderate image and have capitalised on growing resentment of immigration. To sum up, these parties are more pragmatic than the populist parties of the 1990s and operate within the constitutions of their respective countries.

This second generation of right-wing parties can be described as more moderate in terms of 'making no mistakes' that would allowed opponents to portray them as new fascists or Nazis. Marine Le Pen would not describe the holocaust as 'a small detail in history' (as her father did), and Strache would not mention a 'proper employment policy in the Third Reich' as an attack on the current national government (as Jörg Haider did in 1991 during a 
parliamentary debate in Carinthia). The new generation is not anti-Semitic, or even anti-Israel. Geert Wilders, who has visited Israel many times and therefore has many contacts there, is in fact a great friend and supporter of Israel. Wilders has little in common with the Le Pens or Haiders of Europe, who appeal to primitive instincts. Geert Wilders is egocentric, but he is not a racist. Strache visited Israel in December 2010 to sign a declaration over the country's right of existence. This is the opposite of Jörg Haider, who visited Saddam Hussein when the latter was already isolated from the international community, and provoked an international scandal. Strache plays the game of international politics. Timo Soini of the True, meanwhile called The Finns, whose master's thesis written many years ago at the University of Helsinki was, significantly, on populism, also shows no racist or radical features. It would be a mistake for political opponents of these populists would to put them in the racist, extremist corner, which would actually help Strache, Wilders and Co.

The successions and reinventions of leadership within such parties play a crucial role, because these parties are very dependant on the charisma of their leaders. A charismatic leader (like Max Weber) embraces the task assigned to him and demands obedience and loyalty in the pursuit of his 'mission' (as used in its original religious sense). Success is decided by whether or not he accomplishes it. If those to whom he devotes himself should fail to recognise this mission, then the claim to leadership will fall apart. The leader is recognised as such for as long as he knows how to retain recognition by 'proving his worth' (Weber, 1956).

The 'power recognition' granted to these parties differs from country to country, ranging from toleration (as minority governments in Norway, Denmark and the Netherlands) to coalition (in Italy, briefly in Austria and the Netherlands, under consideration in Finland) to a strict cordon sanitaire (Belgium and France). It is hard to say what the right strategy is. Empirically, populist parties often lose credibility in government, whereas they have a good position in minority governments ('power without responsibility').

Right-wing populist parties are easy to distinguish not only from established parties but also from right-wing extremist parties by their fundamental affirmation of the existing system. They use simplistic political formulas and reinforce the prejudices of the population. Thanks to this approach, the European political stage becomes an ideal projection screen for them, as it can be stereotypically charged with being 'complex and removed from the citizens'. Right-wing populism declares its scepticism towards a coalescing Europe. Right-wing populist political parties use existing sentiments in the populace against a Europe that is supposedly ruled by the EU at the cost of one's own national identity. The EU is generally regarded with great distrust, as expressed by the slogan 'Europe yes, EU no!' Right-wing populists warn against a massive loss of national sovereignty and identity to the institutions in Brussels, which according to this logic obviously lack proximity to the citizens and democratic legitimation.

How closely Western European right-wing populism and Euroscepticism are combined is illustrated by statements of the right-wing populist prototype, the late Jörg Haider. The former leader of the Freedom Party of Austria (which became part of a coalition government in 2000, leading to sanctions by the EU Member States), continuously agitated against the EU and used it as a scapegoat. To Haider, the EU was the symbol of a bureaucracy out of control and an attack on the sovereignty of Austria. Thus he remarked, 'The EU of today is capable of anything: it can reach deep into the daily lives of every one of us . . ., without offering any securities. . . The EU is beginning to interfere in areas of life it should have nothing to do with. . . A great many decrees, eighty percent of our laws are made by appointees and not by elected representatives in Brussels' (Haider 1994, 181). It was also Haider who initiated the referendum against the accession of his country to the EU in 1994. Of course there are also populists such as the currently successful Dutch Geert Wilders-his party tolerates the government for whom Europe as a political theme plays only a minor role, in his case as a 'bastion against Islam' (Vossen, 2011).

Contrary to right-wing extremist positions, however, right-wing populists do not oppose the process of European unification as such. They primarily criticise how it proceeds, not that it does. The subject of the EU can be instrumentalised in various ways. Thus populists can denounce the weakness of European foreign and security policy and propagate a Christian-Western bastion against Islam in a typically simplistic manner. Or they may decry the free movement of people and goods in the single European market, making it responsible for organised crime. They rely upon politically exploiting the powerful potential of anti-European sentiments. Some right-wing populist parties act ambivalently towards the EU, especially concerning immigration, where they often evoke a 'fortress Europe'. Populists who want to survive in politics will apparently not call for a boycott of the EU but will seek to promote and market Europe as an economic and cultural 'fortress'.

Euroscepticism in Western Europe is characteristically complex. The causes of this lie in the history of the process of European integration. In particular, the six founding nations of the European Community have been 
sensitised by the shadows of a past spoiled by National Socialism and by the experiences of the Second World War. Besides economic considerations, humanism, security and peace in Europe were considered important aspects of the European Community. These ideas still are of great importance today and have thus been integrated into the political party systems of the Member States (Pelinka, 2007).

Although the EU can be described as a new form of multilevel politics or a partial polity, it is one where the ultimate authority remains with national governments in areas that affect the core of national sovereignty, even if Member States have agreed to transfer the micro-level supervision of day-to-day policymaking to EU institutions in areas such as the single European market and the euro. The fact that the internal decision-making process of the EU is based on consensus dictates the need to achieve broad majorities in order to make decisions in strategic policy areas. Whereas great progress has been made in the Europeanisation of national polities, economies and societies since the Treaties of Rome, this has not been matched by steady progress towards a European identity. In fact, the opposite has happened. Increasing integration has been met by rising Euroscepticism within many national societies, even in those Member States that have traditionally been very integration-friendly, such as France and the Netherlands. The current euro crisis poses a threat not just to the common currency and to economic and monetary union upon which the lack of economic governance and a common tax policy already casts doubt but also to European solidarity and therefore to the EU. It indicates a cleavage within the eurozone between the 'givers' and the 'takers', North and southern countries. The crisis, which essentially comes down to near-bankrupt countries sharing a currency with exporting giants like Germany, could enforce the new Euroscepticism and create a new line of conflict within the old Member States.

Right-wing Eurosceptical forces created quite a furore in the European elections of 2009, whereas the European-wide project Libertas failed: in the Netherlands, right-wing populist Geert Wilders's right-wing party (PVV), founded in 2006, gained almost $17 \%$ of the vote in its first participation in European elections, making it to second place. Austria's FPÖ was able to double its percentage of votes to $12.7 \%$. Moreover, the Alliance for the Future of Austria (BZÖ), founded by Jörg Haider as an act of revenge against his former party, was able to amass $4.58 \%$ of the vote. Including the amazing support (17.7\%) for the former correspondent of Der Spiegel, Hans-Peter Martin, and his 'Dr Martin's List', the three Eurosceptics together won the most votes, ahead of the two governmental parties, the Social Democratic Party of Austria (SPÖ) and the conservative Austrian People's Party (ÖVP). Martin is a former leading candidate without party affiliation for the SPÖ in the European elections of 1999, considered an EU rebel for exposing the non-attendance of EU representatives in sessions of Parliament and their corruption in general by filming them. But Martin did not run on a right-wing populist platform with typical themes such as anti-integration or immigration. Despite this success, and apart from the traditionally Eurosceptic (though for completely different motives) countries of Great Britain and Austria, Europe as a political topic is generally not a central campaign issue in Western Europe. In Germany, for example, the issue plays a minor role in the applied debate among political parties (De Vries, 2007; Decker \& Hartleb, 2008).

Despite the fact that unqualified Eurosceptical positions are held by parties of diverging political persuasions, there are no indications that camps of both the left and the right could establish an effective coalition against European integration (Tiemann, 2006). Euroscepticism is a highly heterogeneous phenomenon (Hartleb, 2010). The significance of Euroscepticism for political parties is strongly dependent on individual national party systems. Taggart and Szczerbiak (2008a), for example, identify three, admittedly assailable, categories in country surveys:

- hardly any relevance: France, Germany, Italy, Belgium, the Netherlands (before the success of Geert Wilders), Luxembourg, Spain, Portugal, Finland (before the success of the True Finns), Ireland and Slovenia;

- the subject of open, coherent and intense political debate: Great Britain, Greece, Sweden, Austria, Malta, the Czech Republic, Denmark and Norway;

- $\quad$ the subject of highly incoherent and changing debate: Poland, Hungary, Slovakia, Latvia, Lithuania and Estonia.

How quickly the picture can change is demonstrated in the case of Finland. In the recent parliamentary elections of 17 April 2011, the Eurosceptical party True Finns mobilised against the EU-supported bailout of Portugal, gaining almost $20 \%$ of the vote in their first national election. The party campaigned on vetoing financial aid to the debtor countries and on renegotiating the bailout agreement. Party leader Timo Soini gained EU experience because of his status as a Member of the European Parliament and his brief involvement in the Libertas project before European elections of 2009. Until 2011, the issue of controversial debates on the EU had not been a major political priority, reflecting a silent acceptance of successive governments' pro-European stance. With the rise of 
the True Finns, the dividing line between those in favour of European integration and those more critical of it has become an electoral one. It appears that the image of a politically debated Euroscepticism will remain a changing one. Whether Euroscepticism will have a future, be it as an ideology or as a political strategy, will therefore depend upon national and European political elites successfully campaigning for Europe and the EU, and taking concrete steps to develop a European demos.

\section{Hard-core Euroscepticism as a Distinguishing Feature of Pan-European, Anti-democratic Right-wing Extremism}

Right-wing extremist ideology has its roots in nationalism, xenophobia and racism. It is governed by the idea that ethnic affiliation with a nation or race is of the utmost importance to an individual. All other interests and values, including civil and human rights, are subordinated to this. Right-wing extremists propagate a political system in which the state and the people amalgamate as an alleged natural order to form a unity ('ideology of the ethnic community'). This results in an anti-pluralistic system, although such extremists accept democratic rules regarding elections, parliamentary rules such as the majority and so on. Features of all types of extremism (including left-wing extremism and fundamentalism) include

- dogmatism

- use of conspiracy theories

- anti-constitutionalism

- friends-versus-enemies stereotypes

- $\quad$ economic anti-liberalism

- utopianism

In addition, European right-wing extremism is based on

- ultra-nationalism (the ideal of an ethnically cleansed nation state)

- $\quad$ xenophobia

- $\quad$ racism

- $\quad$ anti-Semitism (partially shared with left-wing extremism; Chryssogelos 2011)

- ideologically based anti-Americanism (partially shared with left-wing extremism; Chryssogelos 2011)

- a politics of attacking minorities

Few directly anti-constitutional right-wing forces are able to gain as much as $1 \%$ of the vote in national elections in Europe. The most successful example, and as such an exception in Europe, is the Jobbik party in Hungary. In the European Parliament elections of June 2009, this was a new right-wing extremist force in Hungary that created an uproar. Jobbik, recently founded in 2004 by anti-Communist students, received $14.8 \%$ of the vote in their first run and became the third-strongest political force in the country, trailing the Socialists. In the national elections of 2010 Jobbik even got $16.7 \%$. The name Jobbik is a revealing pun in Hungarian, being a grammatical comparative of 'good' and 'right'. In Greece, with Golden Dawn, a party similar to Jobbik, entered national parliament in 2 elections (May \& June, 2012) as a result of the deep crisis of the country which developed to be a 'failing state' dependent on international and European help. In Germany the National Democratic Party of Germany (NPD) is irrelevant nationally and declining as well, but is represented in two state parliaments in eastern Germany, those of Saxony and Mecklenburg-Pomerania. Currently, as a consequence of financial, personal and strategic struggles, the weak right-extremist forces of the NPD and DVU (German People's Union) are planning a merger to strengthen themselves.

The issue of 'Europe' has little attraction from a right-wing extremist perspective, as their counterproposal of a 'Europe of sovereign nations' is less attractive than it is when employed by moderate right-wing populist groups that are able to succeed with voters from other social segments than the purely ideologically motivated protest voters. Right-wing extremist formations participate in the elections rather than boycotting them.

Table 4. Right-wing, anti-democratic extremist forces throughout Europe, according to results in the European Parliament elections 


\begin{tabular}{|c|c|c|c|c|c|}
\hline \multirow[b]{2}{*}{ Country } & & \multirow[b]{2}{*}{ Political Party } & \multicolumn{2}{|c|}{ Latest national elections } & \multirow{2}{*}{$\begin{array}{c}\text { European } \\
\text { elections } \\
2009 \\
\text { Results }^{2}\end{array}$} \\
\hline & & & Date & Results $^{1}$ & \\
\hline Hungary & $\square$ & $\begin{array}{l}\text { Movement for a Better Hungary (Jobbik } \\
\text { Magyarországért Mozgalom - JOBBIK) }\end{array}$ & $\begin{array}{c}11 \text { and } \\
25 / 04 / 2010\end{array}$ & $16.7 \%$ & $14.77 \%$ \\
\hline Bulgaria & & Attack (Ataka - ATAKA) & 05/07/2009 & $9.4 \%$ & $11.96 \%$ \\
\hline Greece & E & Golden Dawn (Chrysi Avgi) & $17 / 06 / 2012$ & $6.92 \%$ & $0.46 \%$ \\
\hline Romania & & $\begin{array}{l}\text { Greater Romania (Partidul România Mare - } \\
\text { PRM) }\end{array}$ & $30 / 11 / 2008$ & $3.2 \%$ & $8.65 \%$ \\
\hline $\begin{array}{l}\text { United } \\
\text { Kingdom }\end{array}$ & Dis & British National Party - BNP & 07/05/2010 & $1.9 \%$ & $8.38 \%$ \\
\hline Slovakia & & $\begin{array}{l}\text { Slovak National Party (Slovenská Národná } \\
\text { Strana - SNS) }\end{array}$ & $10 / 03 / 2012$ & $4.55 \%$ & $5.56 \%$ \\
\hline Slovenia & & $\begin{array}{l}\text { Slovenian National Party (Slovenska } \\
\text { Nacionalna Stranka - SNS) }\end{array}$ & $21 / 09 / 2008$ & $5.4 \%$ & $2.88 \%$ \\
\hline Italy & & $\begin{array}{l}\text { The Tricolour Flame Social Movement } \\
\text { (Movimento Sociale Fiamma Tricolore - } \\
\text { MSFT) }\end{array}$ & $13 / 04 / 2008$ & $2.4 \%$ & $0.79 \%$ \\
\hline Germany & & $\begin{array}{l}\text { German People's Union } \quad \text { (Deutsche } \\
\text { Volksunion - DVU) }\end{array}$ & $27 / 09 / 2009$ & $0.1 \%$ & $0.4 \%$ \\
\hline $\begin{array}{l}\text { Czech } \\
\text { Republic }\end{array}$ & & National Party - Narodni Strana & 2010 & $0.17 \%$ & $0.26 \%$ \\
\hline Germany & & $\begin{array}{l}\text { National Democratic Party of Germany } \\
\text { (Nationaldemokratische Partei Deutschlands } \\
\text { - NPD) }\end{array}$ & $27 / 09 / 2009$ & $1.8 \%$ & - \\
\hline
\end{tabular}

Sources: ${ }^{1}$ http://www.parties-and-elections.de, accessed 13 May 2011; ${ }^{2}$ European Parliament.

A particularly dogmatic form of Euroscepticism arises at the margins of the political system, especially when irreconcilable, ideologically motivated goals are articulated by Communist or xenophobic forces. While right-wing populists are often soft Eurosceptics, right-wing extremists are hard-core Eurosceptics who often reject the idea of Europe for fundamental reasons. The German NPD, for example, which is represented in neither the national nor the European Parliament, seeks entirely new directions for Europe and proclaims it wants to disband the EU as a symbol of political globalisation completely. The EU serves as a symbol of heteronomy. From the NPD's point of view, Germans have lost their sovereignty to the EU. At this point the NPD becomes inconsistent in that it appeals to democratic principles that it otherwise rejects outright in some instances (Hartleb 2009b).

With slogans such as 'Hungary belongs to the Hungarians', the Hungarian Jobbik party is not only right-wing extremist, anti-Roma and anti-Semitic, but also hard-core Eurosceptic (Barlai and Hartleb 2010). The face of the campaign for the European elections, on central display on all election posters, was Krisztina Morvai. She was formerly a women's rights activist, working on the expert committee of the United Nations and lecturing on criminal law at the public Loránd Eötvös University in Budapest, but has since become a fanatic right-wing extremist. Morvai, born in 1963, was asked by the German daily newspaper Die Welt in 2010: 'You were elected to the European Parliament, but you obviously don't like your job. How otherwise can you explain why Jobbik is fighting for Hungary's exit from the EU?' Her answer was, 'We are not categorically for an exit from the EU. But we oppose the creation of a European Empire. We reject robbing the nation states of their decision-making 
power and transferring it to the institutions of the EU. There are no checks and balances on the EU Commission. That is abominable and undemocratic. I am Eurosceptic, but of the hope that we can change the EU. But if worst comes to worst and we are unable to renegotiate the moratorium on land sale which expires in 2011, then Hungary should leave the EU. We shouldn't relinquish our country. The EU needs Hungary more than Hungary needs the EU' (Morvai, 2010).

Another latecomer was the right-wing extremist League of Polish Families (LPR), created on 30 May 2001 as a coalition of nationalist and Catholic groups. In their first participation in national elections they reached $7.9 \%$ of the vote, and in 2005 they received $8 \%$. Their expressed aim in creating the party was the development of Poland as an independent, sovereign nation. From the beginning, the EU served as an enemy. Their Euroscepticism came in many guises: first the rejection of Poland's accession to the EU, and later the demand for a reversal of all further integration (the LPR's stated aim is the 'status quo ante', referring to the Maastricht Treaty) and the opposition to any further integration in the future. Chris Flood characterised exactly this position of the 'status quo ante' as the revisionist variety of Euroscepticism (2002). In the summer 2005 there were even physical attacks on homosexuals, using the slogan 'Paedophiles and pederasts are EU enthusiasts' (Szacki \& Lizut, 2005). The party addressed the voters who had lost in the collapse of Communism and the transition to democracy, but it has since disappeared into irrelevancy, even after having been the junior partner in government for a short time.

The direct connection between right-wing extremism and hard-core Euroscepticism is not exclusive, since left-wing extremist forces also stand in opposition to the EU (De Vries \& Edwards, 2009). The Danish socialists, for example, sought to overthrow capitalism in the 1970s and initiated the Eurosceptical Popular Movement against the EC (Ersson, 2008). The Communists of Bohemia and Moravia, a Czech party, fought every step of European integration prior to the Czech Republic's accession to the EU. It can be said that movements at the margins of the political spectrum are generally Eurosceptical, though their motivations are admittedly diverse: racism, nationalism, anti-capitalism and anti-neoliberalism. In other words, the issue of 'Europe' is useful for extremist forces to 'update' their profiles. The Communist Party of Greece, which got 8.35\% of the vote and two seats in the European elections of 2009, attacks Europe from its still-Communist agenda and tried to build up an opposing force against the Treaty of Lisbon with other parties, such as the Communists of Bohemia and Moravia. They argued that the treaty.

- 'would represent a new qualitative leap in the configuration of the European Union as an economic, political and military block contrary to the interests of the workers and the peoples';

- $\quad$ is impregnated with neo-liberal policies that will further jeopardise economic and social gains of the workers and the peoples'; and

- 'promotes the militarisation of the European Union within the framework of NATO and in coordination with the USA' (Joint position of Communist Workers 2007).

In general, features of left-wing extremism are

- collectivism

- $\quad$ attacking liberal values

- $\quad$ attacking neoliberal values

- anti-fascism

- $\quad$ nostalgia for the Communist past

To sum up, hard-core Euroscepticism can be regarded as a significant feature of extremism which is based on dogmatism. Dogmatism in this context means the belief that one's own country should withdraw from the EU. The Hungarian Jobbik party has many dogmatic features, such as being anti-Semitic, anti-Roma, anti-democratic and also Eurosceptical. But of course, even this hard-core, Eurosceptic force took the opportunity to run for European elections and become a part of Brussels from this perspective.

\section{Euroscepticism in Eastern Central Europe}

One might hypothesise that due to their centrality in the legislation, and given recent foreign policy ambitions of the post-Communist states, EU issues are far more relevant in Eastern Central European accession countries than in Western Europe. In the 1990s the issue of 'Europe' was a more salient and less controversial topic, with some exceptions such as Poland. The tempting attainment of membership in the European club was seen as essential to the development of these nation states. The 1993 package of Copenhagen criteria thus correlated strongly with most of the platforms of the reform-oriented parties in Eastern Europe. 
The desire to establish democracy and the rule of law, combined with the need for protection from a neo-imperial Russia and the defence of human rights and minorities, seemed to accompany the aspirations for a functioning market economy. Thus, on 15 February 1991, a Declaration of Cooperation was signed in the Hungarian Visegrád, located north of Budapest. Three states participated in this agreement: Poland, Hungary and then-Czechoslovakia, which subsequently split into the Czech Republic and Slovakia. The declared goals of the now four 'Visegrád states' were to overcome dictatorship and establish democracy and a market economy, as well as achieve European integration. The central issue was an irreversible and definite Westernisation of their respective countries. The Copenhagen criteria thus were aimed at urging the domestic parties into legislative acceptance of the Community acquis. The actual, successful accession negotiations were connected to this pro-European course. The same applied later to such states as the Baltic countries, Slovenia, Bulgaria and Romania.

However, serious conflicts arose after accession, and in Poland they emerged as early as the 1990s. The internationally renowned Hungarian political scientist Attila Ágh, for example, speaks of a 'new conflict of values' between Eurosceptics and supporters of Europe that is increasingly illustrated in poll results. According to this EU expert, EU-related issues have come to be among the most intensely discussed subjects in the media and in parliamentary debates (Ágh, 2006). Euroscepticism has fundamentally different motives in the old and new EU Member States (Hartleb, 2009a). The currently much-discussed 'post-EU-accession syndrome' (Ágh, 2008) in Eastern and Central Europe is the consequence of disappointed expectations, particularly regarding economic development, having a direct impact on the political contest. To compensate for the lack of national freedom to act, soft Euroscepticism is often employed as a strategic instrument of national power play or domestic muscle flexing this alongside the existing hard-core Euroscepticism articulated by right-wing extremist parties.

In the Czech Republic and Poland, Euroscepticism is often combined with anti-German sentiments in the argument that the EU is too deeply linked with Germany and its efforts to promote European integration. In the case of the Czech Republic, soft Euroscepticism was long considered to be dominant, exemplified by the Civic Democratic Party (ODS). This formation supported the Czech Republic's course on Europe when it was in government under Václav Klaus between 1993 and 1997. But internal party conflicts and the transition from governing party to the opposition led to Klaus's dismissal as party chair and the rise of Mirek Topolánek as a rival within the party ranks. Eurosceptical utterances increased during this phase, articulated principally by Klaus. Surprisingly, he was elected President of the Czech Republic in 2003. He labelled himself an EU dissident in 2008 , but this was no longer a majority position in the party he himself had influenced so much. Towards the end of 2008, Klaus declined to accept the position of honorary party chair, after having to recognise his minority position. Then Prime Minister Mirek Topolánek was able to unify a majority current within the ODS behind his support of the EU reform process, in order to ensure a smooth EU presidency for the Czech Republic in the first half of 2009 .

Klaus naturally sought to symbolically counter this intention, for example by stating that he would not fly the EU flag from the Prague Castle. Klaus declared the Irish 'No' in the referendum 'a victory for freedom and reason over artificial, elitist projects and the European bureaucracy' and pronounced the Lisbon Treaty 'dead'. He rejects the Reform Treaty, seeing it as an extensive disempowerment of national sovereignty. In the Austrian tabloid paper Kronenzeitung he expressed his standpoint thus: 'I too am pro-Europe, and I value my affiliation with European culture and civilisation very highly but Europe is not the EU and Brussels. The EU representatives do not have the right to appropriate Europe, but they do this all the time, and that to me is the main problem of our times. Europe belongs to all of us, not just to them' (Klaus, 2008).

Eurosceptical potential in the Visegrád states varies significantly. The results of a 2004 Gallup poll showed 43\% in the Czech Republic and Slovakia as Eurosceptical, on par with the traditionally Eurosceptical Western Europeans from Great Britain (46\%) and Austria (41\%). Poland polled closely behind the first two states, with $41 \%$ of its population considering themselves Eurosceptics. In Hungary, on the other hand, only $16 \%$ of the population stated their opposition to the EU, thereby ranking behind even France (28\%) and Germany (27\%) (Gallup, 2004; Weßels, 2007). The rejection of hard-core Euroscepticism in the Visegrád states correlates with the strong increase in approval of EU membership by these countries' populations. In the winter of 2006/2007, the approval rate in Poland for the EU reached a maximum of $88 \%$, up $24 \%$ from the time of its EU accession in May 2004 (CBOS 2006). The obvious shift in attitudes of the population prevented the Polish government under the leadership of the Law and Justice Party (PiS) from escalating the conflict with the majority of the EU partners and sabotaging the EU reform process at the Brussels summit in June 2007. Following the status quo, after the ratification of the Lisbon Treaty, the Euroscepticism debate subsided in the Czech Republic and in 
Poland. In summary, one might record the following concerning the interrelation of population and party constellation: most often the Euroscepticism of the parties is congruent with the attitudes of the population. It seems that the political elites' discourse affects the population significantly, functioning as a personalised articulation of criticism, scepticism and even rejection. When one analyses Eastern Europe more broadly, for example, one finds that 'Europe' is only of minor importance as an issue of party politics in the Baltic States.

Table 5. Radical left- and right-wing parties in Central Europe (V-4 countries)

\begin{tabular}{|c|c|c|c|c|}
\hline \multirow[b]{2}{*}{ Country } & \multirow[b]{2}{*}{ Political Party } & \multicolumn{2}{|c|}{$\begin{array}{l}\text { Latest national } \\
\text { elections }\end{array}$} & \multirow[t]{2}{*}{$\begin{array}{c}\text { European } \\
\text { elections } 2009\end{array}$} \\
\hline & & Date & Result & \\
\hline Slovakia & $\begin{array}{l}\text { Slovak National Party (Slovenská Národná } \\
\text { Strana - SNS) }\end{array}$ & $10 / 03 / 2012$ & $4.55 \%$ & $5.56 \%$ \\
\hline Hungary & $\begin{array}{l}\text { Movement for a Better Hungary (Jobbik } \\
\text { Magyarországért Mozgalom - JOBBIK) }\end{array}$ & $\begin{array}{c}11 \text { and } \\
25 / 04 / 2010\end{array}$ & $16.7 \%$ & $14.77 \%$ \\
\hline Poland & Self-defence (Samoobrona) & $21 / 10 / 2007$ & $0.02 \%$ & $1.46 \%$ \\
\hline Poland & $\begin{array}{l}\text { League of Polish Families (Liga Polskich } \\
\text { Rodzin - LPR) }\end{array}$ & $21 / 10 / 2007$ & $1.3 \%$ & - \\
\hline $\begin{array}{l}\text { Czech } \\
\text { Republic }\end{array}$ & $\begin{array}{l}\text { Communist Party of Bohemia and Moravia } \\
\text { (Komunistická Strana Čech a Moravy - } \\
\text { KSČM) }\end{array}$ & $29 / 05 / 2010$ & $11.3 \%$ & $14.8 \%$ \\
\hline
\end{tabular}

The third-strongest force in the Czech political landscape is the Communist Party of Bohemia and Moravia, which can be seen in many ways as an anti-system party. Its Euroscepticism, however, has become somewhat more moderate. Before the Czech Republic's accession to the EU, the party had spoken out early against any participation in the process of European integration (Hough \& Handl, 2004). After entry into the EU a policy of fait accomplis led to acceptance of the status quo. This arrangement also becomes evident in the fact that the Communists participate in the European elections rather than boycotting them. European security policy, however, is still a thorn in their side. Soft Eurosceptical views are generally held by cultural-societal authoritarian parties and/or those that defend protectionism. In Eastern Central Europe this is true for a whole range of centre-right parties. Strategic aspects should not be overlooked in explaining this fact and soft Euroscepticism as such. The main empirically relevant aspect in this context is the connection between the role of the opposition and the option of strategically mobilising Eurosceptical voter potential in the political contest.

To sum up, Euroscepticism in Central and Eastern Europe has different roots than it does in Western Europe, as the example of the Visegrád states demonstrate. Eurosceptical potential in the Visegrád states varies significantly and was expressed by political elites in the Czech Republic and Poland. Currently, these voices have become silent, which can be interpreted as a successful turn to integration and identification.

\section{European-wide or Non-populist Eurosceptical Projects}

Only in a few exceptions has the process of European integration led directly to Eurosceptical party projects. In Germany, for instance, Manfred Brunner, the former cabinet chief to EC Commissioner Martin Bangemanns, founded an anti-euro party in 1994 called the Alliance of Free Citizens, which sought to prevent the establishment of the common European currency. The issue proved itself to have no mobilising potential, even if there was no referendum in Germany on the issue. The party achieved only $1.1 \%$ in the European elections of 1994. Even leaving the image of a single-issue party behind could not help this movement (Hartleb, 2007). Most recently, however, activities directed towards establishing a party entirely based on Euroscepticism have been increasing. In the traditionally Eurosceptical Great Britain, the UKIP came in second in the 2009 European elections, with $16.5 \%$ of the vote. The party seeks Great Britain's exit from the EU. In Austria, Hans-Peter Martin ran for the Liste Dr Martin (Dr Martin's List) founded by him, denouncing corruption in the EU and the European Parliament in particular as a central campaign issue. In European elections of 2004, the newly founded List gained 14\% of the vote, reaching third place. In 2009 Martin received $17.7 \%$ of the vote. 
The political party Libertas emerged from a citizens' initiative in Ireland that campaigned successfully against the Reform Treaty in the first vote, and unsuccessfully in the second vote. Declan Ganley, an entrepreneur and multimillionaire, has played a decisive role in supporting this project. Libertas could be described as an ideal type of soft Eurosceptic, pro-European integration party, but opposed to some features of the EU system. It also supports the role of European defence. Ganley himself has adopted an interesting communication strategy. He has repeated that Libertas is a pro-European organisation, that there is no future for Euroscepticism (Note 3) and that the EU is necessary. Libertas stands for democracy and a better EU. Ganley has stated that an increasingly anti-democratic and overbearing Brussels represents the greatest risk to the success of the EU. The majority of his speeches insist on the existence of a huge gap between an unaccountable elite in power in Brussels and the urgent necessity to give powerless citizens (people, individuals, families and communities) a say in order to fulfil their potential. The succession of treaties giving more power to this unelected elite and the low turnout figures are the proof that the EU is ignoring the voice of the people. Of course, Libertas would embody a popular frustration against centralised power and represent the vote of the people.

Libertas attempted to become a political party at the European level. To be recognised at this level, a party must have members from at least one-quarter of EU Member States who represent the party in the European Parliament, and a national parliament or a regional parliament or assembly. Libertas named the following eight members from seven Member States:

- $\quad$ Lord Alton of Liverpool (UK, House of Lords)

- $\quad$ Philippe de Villiers (France, European Parliament, Mouvement pour la France, Ind/Dem)

- Paul-Marie Coûteaux (France, European Parliament, Mouvement pour la France, Ind/Dem)

- Georgios Georgiou (Greece, European Parliament, Popular Orthodox Rally, Ind/Dem)

- Timo Soini (Finland, Parliament of Finland, True Finns)

- Igor Gräzin (Estonia, Riigikogu, Estonian Reform Party, ALDE)

- Mintcho Hristov Kouminev (Bulgaria, National Assembly of Bulgaria, Ataka, NI)

- $\quad$ Andrzej Gutkowski (Poland, Masovian Regional Assembly)

Later, Soini from the True Finns expressed his scepticism towards the whole project, while prominent figures such as Czech President Václav Klaus supported it. The process of creating a platform for European Parliament elections could be described as difficult and disappointing, as a summit in Rome on March 2009 demonstrated. In the push to recruit candidates across the entire political spectrum in all 27 Member States, Libertas has minimally defined its view as: 'The EU urgently needs reforming and revitalising. We want a strong Europe, based on democratic accountability.' (Note 4) New national parties established by Libertas have names in the 'Libertas X' format (e.g., 'Libertas Sweden'), and pre-existing national parties have been asked to change their names to include the word 'Libertas' in the title, although the latter approach has not met with unalloyed success.

Beyond its position on democracy in Europe, Libertas's social and economic positions aim to be centrist, in order to attract people from across the political spectrum. Also, Libertas supports some reforms against EU democratic deficits, such as the elections of commissioners. Libertas argues that a strong defence policy would be necessary for the EU. Its positions have been rather confusing and not expressed in a simple, populist agenda. To sum up, Libertas can be regarded as a soft Eurosceptical force in favour of European integration, but against some features.

In May 2009, former Polish President Lech Wałęsa spoke at a Libertas meeting (Gagatek, 2009). Wałęsa's speech provoked a lengthy debate in the Polish media, coming only a day after he had made a similar high-profile appearance at the campaign launch of the EPP in Warsaw. This Polish symbol of systemic change and civic courage in dictatorship received $€ 100,000$ from Ganley for his contribution. After some disagreements with the Polish leaders of Libertas, Wałęsa distanced himself completely from the movement. The whole campaign 'was a sign of weakness and showed the lack of any real programme base' (Gagatek, 2009). Libertas participated in the European elections of 2009 in several European countries (12 Member States altogether), but only won a seat in France, with Philippe de Villiers. Since the second Irish referendum, this formation has practically disappeared and has ceased all public relations work. It can be concluded that the case of Libertas represents

- the failure of an ambitious attempt to build up the first genuinely transnational Eurosceptical party;

- a lack of unity within transnational Eurosceptical projects; 
- the many difficulties in building up a clearly elaborated platform, an indicator of Euroscepticism as a very heterogeneous phenomenon;

- in general, a renewable project; but also

- a huge challenge to create a European-wide campaign, as long as European elections are still based on national logic.

\section{A Unifying Force? Euroscepticism in the European Parliament}

Within EU institutions and organs, Eurosceptical formations are able to articulate their influence and their viewpoint principally and directly only in the European Parliament. Due to fragmentation into several groups and to alliances with EU-friendly forces, however, there is no larger Eurosceptical formation (Benedetto, 2008). When looking at the European policy positions of representatives in the European Parliament, it becomes clear that Eurosceptics are a small minority.

Attitude research has identified four types of Eurosceptical representatives:

1. the anti-EU representative, who distrusts and rejects the entire project of European integration;

2. the minimalist, who criticises certain aspects;

3. the reformist, who after taking critical toll of the current situation seeks reforms; and

4. the resigned representative, who rejects the project of integration but collaborates with it due to lack of alternatives.

In November 2007, 180 of the total (at this time) of 785 Members of the European Parliament could be identified as one of these types (Costa \& Brack 2009).

After the European elections of 2009 we are left with an unclear and changing picture. Eurosceptical forces identified in the European Parliament after 2009 include the following:

- Libertas (emerged from the first 'No' in Ireland): just one seat; the failure of a European-wide Eurosceptical movement;

- Europe of Freedom and Democracy: a genuinely Eurosceptical faction, includes the British UKIP; small and heterogeneous;

- European Conservatives and Reformists: EPP dissidents, main players; British Conservatives and Czech ODS as well as the Polish PiS; heterogeneous;

- $\quad$ no right-wing extremist faction: the last futile attempt to create one failed in 2007, thus there are many representatives from right-wing parties without a faction, such as Jobbik;

- $\quad$ non-right-wing extremist Eurosceptics without a faction (such as the Austrian Liste Dr Martin): most of the altogether 35 MEPs who have an independent status in the Parliament;

- partial Euroscepticism: within the Socialist faction, the Confederal Group of the European United Left/Nordic Green Left.

The smallest faction in the European Parliament that can be described as Eurosceptic is Europe of Freedom and Democracy (EFD). In traditionally Eurosceptic Great Britain, the UKIP became the second-strongest party in Britain, with $16.5 \%$ of the vote. Besides the Britons, the EFD comprises representatives of the regionalist, right-wing populist Italian Northern League as well as of the right-wing extremist Slovak National Party, which participated in that country's social democratic coalition government between 2006 and 2010. But even within this faction voting discipline is low, clearly demonstrating its heterogeneity. In past elections, the EFD was far behind the other factions. (Note 5) The UKIP itself has also been characterised by infighting since its success in the European elections of 2009. The party had already received $16.8 \%$ of the vote in 2004, after which the television presenter and UKIP member Robert Kilroy-Silk left the EFD Group in the European Parliament. And after 2009 these turbulences continued. Three of the 13 elected representatives have dropped out of the UKIP as of April 2011. In the previous term, between 2004 and 2009, the UKIP belonged to the Eurosceptical faction Independence and Democracy (Ind/Dem faction); this group, however, did not achieve a sufficient election result to form a faction, partly due to the failure of Libertas. The composition of groups in European Parliament is heterogeneous. Within the Alliance of Liberals and Democrats for Europe (ALDE), the Movement for a Democratic Slovakia (HZDS), the party of former populist-authoritarian leader Vladimír Mečiar, has obtained a membership.

Another Eurosceptic front is unified in the ECR (European Conservatives and Reformists). This is an alliance 
between Western and Eastern European formations such as the British Conservatives and the Czech ODS, who left the EPP-ED Group due to their soft Eurosceptical attitude and the 'loveless marriage' between the EPP and Tories after the European elections of 2009 (regarding the British, see Lynch \& Whitaker, 2009). The Polish PiS also became a member. Towards the end of 2010, four PiS representatives participated in founding the new Polish party called Polska jest Najważniejsza ('Poland is most important'), which gave itself a more moderate conservative direction than that held by the PiS. But the members remained within the ECR faction. Even before that, the British Conservatives and the ODS had sought to create a European Political Party, and attempts before that had led to the founding of a movement for European reform in 2006. The founding manifesto of the ECR underscored the urgent necessity of reforming the EU on the basis of EU-realism, transparency, responsibility and democracy. But with the founding of the faction, conflicts arose. In the opening session of the newly elected European Parliament on 14 July 2009, British ECR representative Edward McMillan-Scott created an uproar by running for vice-president of the Parliament, despite the ECR's having nominated not him but rather the Polish Michał Kamiński (then PiS). McMillan-Scott was elected due to the solid support of the other factions in the Parliament, leaving Kamiński to fail. Later, McMillan-Scott was excluded and joined the ALDE.

Between 1999 and 2009 the Union for a Europe of Nations was established as a faction in the European Parliament. Several radical right-wing populist formations, such as the Danish People's Party (DN), the Italian Lega Nord (LN) and two Polish governing parties around the PiS, the Polish nationalistic populist Samoobrona (Self-defence) and the right-wing extremist League of Polish Families, were active in this group. The group went out of existence due to severe losses in the elections of 2009. Thus the national conservative Italian Allianza Nationale became a member of the Berlusconi alliance Popolo della Libertà (successor party to the Forza Italia) and thereby also of the EPP. Right-wing extremists, generally of the hard-core Eurosceptical persuasion, did not manage to constitute a force of their own in the European Parliament. The right-wing group called Group of the European Right, founded after the second European elections in 1984 under the leadership of the French Jean-Marie Le Pen, has thus far been the only right-wing extremist group in the history of the European Parliament that could sustain its original strength for an entire legislative period (until 1989). The attempt to create another such faction, including the German Republikaner (Republicans) under the leadership of Chair Franz Schönhuber, failed due to the inability to resolve the question of the status of South Tyrol.

There was no right-wing extremist group in the European Parliament in the legislative periods of 1994-99 and 1999-2004. The most recent attempt succeeded only temporarily in 2007, when the faction called Identity, Tradition, Sovereignty (ITS) was created in the attempt to unify right-wing extremists from Western and Eastern Europe. Members of ITS included the FPÖ, the French Front National, the Belgian Vlaams Belang and the Greater Romania Party. The accession of Romania and Bulgaria in particular held the promise of fulfilling legal requirements 20 members from six different countries previously not attainable. The principal objectives of this formation were the fight against the Constitutional Treaty, against tendencies towards centralisation and the rejection of a possible accession of Turkey to the EU, and in favour of the preservation of national identity. The initiators sought for the EU itself to develop as a league of sovereign nation states.

The ITS was dissolved, however, only a few months after its formation a clear indication that a European-wide collaboration of right-wing extremist parties is difficult to organise, thus impeding the crystallisation of a party family capable of acting. The faction dropped beneath the required number of members after five representatives of the Greater Romania Party left in protest over the Italian representative Alessandra Mussolini. The Romanians were outraged at remarks by the granddaughter of 'il Duce' that depicted Romanians in Italy as having a criminal lifestyle. Mussolini was referring to the murder of an Italian woman for which a Roma from Romania was held responsible. Most of the right-wing extremist representatives in the European Parliament actually do not belong to a faction, as national interests often preclude any institutionalised cooperation. This applies to the three representatives of the Hungarian Jobbik, for example.

However, Euroscepticism in the European Parliament does not need be right wing per se. Many leaders of the Socialist Party called for a 'No' in the French referendum of 2005. The faction of the European Left, which has been organised (as of April 2001) into a faction of socialist and post-Communist parties as the Confederal Group of the European United Left/Nordic Green Left, with 35 members, questions the political and economic system of the EU regarding its lack of social and democratic policy. It condemns the current development of the EU as neoliberal and anti-democratic, and therefore dangerous. This faction demands restructuring in all areas of the EU including the economic system; defence, agricultural and climate policies; and even the democratic structure. Despite all of this it would be unjustified to state that the European left and its faction are hard-core unqualified Eurosceptics, because they don't oppose European integration (Özen, 2009). Obviously there are gradations of Euroscepticism within the left as well. 
All in all the Confederal Group seems to take positions as diverse as its member parties do. The fight that broke out in the German socialist party The Left (Die Linke) when the leading candidate in the European elections of 1994, 1999 and 2004, Sylvia-Yvonne Kaufmann, and the former mastermind of the party, Andre Brie, were both relegated to low spots on the party list for approving of the Lisbon Treaty against the party line, exemplified this. Euroscepticism was also expressed in the platform of the party by painting a bleak picture of the EU. The Dutch left-wing populist Socialistische Partij also believes that the nation state 'needs to defend its power of control against the intrusive European Union' (Voermann, 2011).

\section{Conclusion and Perspectives}

The Treaty of Lisbon will be not the 'end of the history', but only an intermediate step for the EU between two permanent challenges: enlargement with more countries, as well as deepening. The European elections of June 2009 showed that there is still much work to do in convincing citizens, not only in the new but also in the old Member States of the EU. The integration process continues to be supported by the governments of Member States so that Euroscepticism will most probably continue to be used as an instrument of opposition parties in national political contests. Euroscepticism is not a mainstream phenomenon in the European political landscape (Ray, 2007), due in part to the limited influence of European integration on national political party systems (Mair, 2000). Despite the fact that significant parts of the European public hold Eurosceptical views, the establishment of a Eurosceptical family of parties fails due to the lack of a common identity, trust and solidarity among the relevant national parties and the lack of a common strategic platform. Euroscepticism can become a rallying point when the economic stability of the EU (the euro) is at risk, as recently happened in Finland. The national and European elites should combat the roots of Euroscepticism nonetheless (Leconte, 2010).

National parties may actually feel that this is exactly what drives Euroscepticism on the national level. The key is to find complementary strategies on both levels. Peter Mair has argued that it would make sense for national parties in national elections to focus on grand political and institutional issues because these are mostly intergovernmental, while Euro parties in European elections should focus on day-to-day public policy issues because this is were the EU has actual competence. Instead, the opposite happens, and national parties are not likely to give up on their primacy in setting the agenda (Mair, 2000). Now with the euro and Schengen crisis, European issues are suddenly becoming domesticated. National parties have to address important European political issues in the domestic setting, and this creates opportunities to address Euroscepticism as well; if Europe becomes a domestic issue (finally), then theoretically a primary source of Euroscepticism distance from Brussels should decrease. But it can also create more space for Eurosceptic forces to mobilise the electorate.

It is unlikely that any right-wing populist or extremist international groups will be formed any time soon. Extremist parties do not have enough potential support to pose a threat to the existing liberal democratic order. The success of the populists also tends to be volatile, as has been shown in the case of the True Finns. As in the past, the EU can have a direct influence on the future of Euroscepticism, or even marginalise it, as the Eurosceptics have so far failed to find common cause and it is unlikely that they will do so any time soon. The differences that exist amongst Eurosceptics suggest that individual cases need to be examined in the context of the individual member state concerned. The problem of nationalistic right-wing populism will continue to be seen at a national level. There is much to suggest that the debate over the future of European integration and of the European Union itself will also continue to have a significant influence on the political debate in individual member states. According to leading European state and government heads, the ongoing 2011/12 crisis has shown that, with greater economic and social integration, some of the obvious design flaws within the Eurozone can be rectified and more stability guaranteed. In terms of legitimacy, this can only be the case if the peoples of Europe and the European Union as a whole subscribe to this view, and not just the political elite. Then there will be no new era of renationalisation. The power of European integration is so strong that it is unlikely that there will be any national U-turns on this issue, despite the occasional upsurge of populism or extremism in individual countries.

\section{References}

Ágh, A. (2006). Eastern enlargement and the future of the EU 27: EU foreign policy in a global world. Budapest: EU-Consent Network.

Ágh, A. (2008). Hungarian politics in the early $21^{\text {st }}$ century: reforms and post-EU accession crisis. Südosteuropa Mitteilungen, 48(2), 68-81.

Barlai, M., \& Hartleb, F. (2010). Rechtsextremismus als Posttransformationsphänomen - der Fall Ungarn. Totalitarismus und Demokratie, 7(1), 83-104. 
Benedetto, G. (2008). Explaining the failure of Euroscepticism in the EP. In A. Szczerbiak, \& P. Taggart (Eds.), Opposing Europe? The comparative party politics of Euroscepticism. Comparative and theoretical perspectives (Vol. 2, pp. 127-150). Oxford: Oxford University Press.

CBOS. (2006). Polish Public Opinion.Warsaw. November.

Chryssogelos, A. (2011). Old ghosts in new sheets: European populists parties and foreign policy. Brussels: Centre for European Studies.

Costa, O., \& Brack, N. (2009). The role(s) of the Eurosceptic MEPs. In Dieter Fuchs, Antoine Roger and Raul Magni-Berton (Eds.), Euroscepticism: images of Europe among mass publics and political elites (pp. 253-272). Opladen/Farmington Hills: Barbara Budrich.

Crespy, A., \& Verschueren, N. (2009). From Euroscepticism to resistance to European integration: an interdisciplinary perspective. Perspectives on European Politics and Society, 10(3), 377-393. http://dx.doi.org/10.1080/15705850903105793

Decker, F., \& Hartleb, F. (2008). L'euroscepticisme en Allemagne: les partis politiques et l'Union européenne. In L. Neumayer, R. Antoine, \& F. Zalewski (Eds.), L'Europe contestée: 'populisme' et 'euroscepticisme' dans l'Union européenne élargie (pp. 34-54). Paris: Michel Houdiard Éditeur.

De Vries, C. E. (2007). Sleeping giant: fact or fairytale? How European integration affects national elections. European Union Politics, 8(3), 363-385. http://dx.doi.org/10.1177/1465116507079546

De Vries, C. E., \& Edwards, E. E. (2009). Taking Europe to its extremes: extremist parties and public Euroscepticism. Party Politics, 15(1), 5-28. http://dx.doi.org/10.1177/1354068808097889

Easton, D. (1975). A re-assessment of the concept of political support. British Journal of Political Science, 5(4), 435-457. http://dx.doi.org/10.1017/S0007123400008309

Ersson, S. (2008). Post-Communist and leftist parties in two Scandinavian countries after 1989. In U. Backes, \& P. Moreau (Eds.), Communist and post-Communist parties in Europe (pp. 141-166). Göttingen: Vandenhoeck \& Ruprecht.

Eurobarometer. (2006). The future of Europe. Brussels: European Commission, May.

Flood, C. (2002). Problematising Euroscepticism. Unpublished paper presented at Queen's University Belfast, Belfast (cited by permission of author).

Fuchs, D., Roger, A., \& Magni-Berton, R. (2009). European cleavage, Euroscepticism and support of the EU: a conceptual discussion. In D. Fuchs, A. Roger \& R. Magni-Berton (Eds.), Euroscepticism: images of Europe among mass publics and political elites (pp. 9-32). Opladen/Farmington Hills: Barbara Budrich.

Gagatek, W. (2009). European political parties as campaign organisations. Brussels: Centre for European Studies.

Haider, J. (1994). Die Freiheit, die ich meine. Frankfurt am Main: Ullstein.

Harmsen, R., \& Spiering, M. (2004). Introduction: Euroscepticism and the evolution of European political debate. In R. Harmsen, \& M. Spiering (Eds.), Euroscepticism: party politics, national identity and European integration (pp. 13-36). Amsterdam/New York: Editions Rodopi.

Hartleb, F. (2007). Bund Freier Bürger Offensive für Deutschland. In F. Decker, \& V. Neu (Eds.), Handbuch der deutschen Parteien (pp. 197-200). Wiesbaden: VS Verlag für Sozialwissenschaften.

Hartleb, F. (2009a). Euroskeptizismus in West- und Osteuropa. In M. H. W. Möllers, \& R. C. van Ooyen (Eds.), Jahrbuch für öffentliche Sicherheit 2008/2009 (pp. 479-484). Frankfurt am Main: Verlag für Polizeiwissenschaft.

Hartleb, F. (2009b). Gegen Globalisierung und Demokratie: Die NPD als eine neue soziale Bewegung im europäischen Kontext? Zeitschrift für Parlamentsfragen, 40(1), 115-127.

Hartleb, F. (2010). Review of A. Szczerbiak, \& P. Taggart (Eds.), Opposing Europe? The comparative party politics of Euroscepticism (Vol. 2). Oxford: Oxford University Press, 2008. In U. Backes, \& E. Jesse (Eds.), Jahrbuch Extremismus \& Demokratie (Vol. 21, pp. 369-371). Baden-Baden: Nomos.

Hartleb, F. (2011). A thorn in the side of European elites. The new Euroscepticism, Centre for European Studies, Brussels 2011.

Hooghe, L., \& Marks, G. (2007). Sources of Euroscepticism. Acta Politica, 42(2-3). 119-127. 
http://dx.doi.org/10.1057/palgrave.ap.5500192

Hough, D., \& Handl, V. (2004). The post-Communist left and the European Union: the Czech Communist Party of Bohemia and Moravia and the German Party of Democratic Socialism. Communist and Post-Communist Studies, 37(2), 319-339. http://dx.doi.org/10.1016/j.postcomstud.2004.06.002

Hix, S. (2005). The political system of the European Union. Houndmills: Palgrave.

Jesse, E., \& Thieme, T. (2011). Extremismus in den EU-Staaten im Vergleich. In Eckhard Jesse and Tom Thieme (Eds.), Extremismus in den EU-Staaten (pp. 431-482). Wiesbaden: VS Verlag für Sozialwissenschaften. http://dx.doi.org/10.1007/978-3-531-92746-6_26

Joint position of Communist Workers' progressive and left-wing parties regarding the European Union treaty. (2007). Retrieved 20 June, 2011, from http://inter.kke.gr/News/2007news/2007-10-portugal-eutreaty//

Klaus, V. (2008). Interview in Österreichischen Kronenzeitung, 20 August. Retrieved 20 November, 2008, from www.klaus.cz

Lane, J., \& Ersson, S. (2007). Party system instability in Europe: persisting differences in volatility between West and East? Democratization, 14, 92-110. http://dx.doi.org/10.1080/13510340601024322

Lang, K. (2007). Beitrittskater und posttransformative Depression. Berlin: SWP-aktuell.

Leconte, C. (2010). Understanding Euroscepticism. Houndsmills: Palgrave.

Lipset, S. M., \& Rokkan, S. (1967). Cleavage structures, party systems and voter alignments. In S. M. Lipset, \& S. Rokkan (Eds.), Party systems and voter alignments: cross national perspectives (pp. 1-64). New York: Free Press.

Lynch, P., \& Whitaker, R. (2009). A loveless marriage: the Conservatives and the European People's Party. Parliamentary Affairs, 61(1), 31-51. http://dx.doi.org/10.1093/pa/gsm047

Mair, P. (2000). The limited impact of Europe on national party systems. West European Politics, 23(4), $27-51$. http://dx.doi.org/10.1080/01402380008425399

Morvai, K. (2010). Ungarn muss notfalls aus der EU austreten. Die Welt, 12 April.

Mudde, C. (2007). Populist radical right parties in Europe. Cambridge: Cambridge University Press. http://dx.doi.org/10.1017/CBO9780511492037

Özen, Y. (2009). Die GUE-NGL Weicher Euroskeptizismus auf breiter Front. Centrum für angewandte Politikforschung, Munich. Retrieved 10 March, 2011, from http://www.cap-lmu.de/themen/europawahl/download/europa09-Oezen-Euroskeptizismus-GUE-NGL.pdf

Pelinka, A. (2007). Bestimmungsfaktoren des Euroskeptizismus. In A. Pelinka, \& F. Plasser (Eds.), Europäisch Denken und Lehren: Festschrift für Heinrich Neisser (pp. 233-247). Innsbruck: Universitätspresse.

Ray, L. (2007). Mainstream Euroskepticism: trend or oxymoron? Acta Politica, 42(2-3), 153-172. http://dx.doi.org/10.1057/palgrave.ap.5500189

Szacki, W., \& Lizut, M. (2005). Polsce niesiem odrodzenie. Gazeta Wyborcza, 2(June), 2.

Szczerbiak, A., \& Taggart, P. (Eds.). (2008). Opposing Europe? The comparative party politics of Euroscepticism (Vol. 2), Comparative and theoretical perspectives. Oxford: Oxford University Press.

Taggart, P. (1998). A touchstone of dissent: Euroscepticism in contemporary Western European party systems. European Journal of Political Research, 33(3), 363-388. http://dx.doi.org/10.1111/1475-6765.00387

Taggart, P., \& Szczerbiak, A. (2004). Contemporary Euroscepticism in the party systems of the European Union candidate states of Central and Eastern Europe. European Journal of Political Research, 43(1), 1-27. http://dx.doi.org/10.1111/j.1475-6765.2004.00143.x

Taggart, P., \& Szczerbiak, A. (2008a). Conclusion: Opposing Europe? Three patterns of party competition over Europe. In A. Szczerbiak \& P. Taggart (Eds.), Opposing Europe? The comparative party politics of Euroscepticism (Vol. 1, pp. 348-363). Oxford: Oxford University Press.

Taggart, P., \& Szczerbiak, A. (2008b). Introduction: Opposing Europe? The politics of Euroscepticism in Europe. In A. Szczerbiak, \& P. Taggart (Eds.), Opposing Europe? The comparative party politics of Euroscepticism (Vol. 1, pp. 1-15). Oxford: Oxford University Press.

Thatcher, M. (1993). The Downing Street years. London: HarperCollins. 
Thatcher, M. (2002). Statecraft: strategies for a changing world. London: HarperCollins.

Tiemann, G. (2006). Euroskeptische Parteien zwischen Strategie und Ideologie. In A. Kutter, \& V. Trappmann (Eds.), Das Erbe des Beitritts: Europäisierung in Mittel- und Osteuropa (pp. 171-188). Baden-Baden: Nomos.

Voermann, G. (2011). Linkspopulismus im Vergleich: Die niederländische Socialistische Partei und die deutsche Linke. In F. Wielenga, \& F. Hartleb (Eds.), Populismus in den Niederlanden und in Deutschland im Vergleich (pp. 179-204). Münster: Waxmann Verlag.

Vossen, K. (2011). Vom konservativen Liberalen zum Nationalpopulisten die ideologische Entwicklung des Geert Wilders. In F. Wielenga, \& F. Hartleb (Eds.), Populismus in den Niederlanden und in Deutschland im Vergleich (pp. 105-128). Münster: Waxmann Verlag.

Weber, M. (1956). Wirtschaft und Gesellschaft: Grundriß der verstehenden Soziologie. Tübingen: Mohr.

Weßels, B. (2007). Discontent and European identity. Acta Politica, 42(2-3), 287-306. http://dx.doi.org/10.1057/palgrave.ap.5500188

Weßels, B. (2009). Spielarten des Euroskeptizismus. In F. Decker, \& M. Höreth (Eds.), Die Verfassung Europas: Perspektiven des Integrationsprojektes (pp. 50-68). Wiesbaden: VS Verlag für Sozialwissenschaften.

\section{Notes}

Note 1. Eurobarometer Source, Spring 2010; Retrieved 15 May, 2011, from http://europa.eu/rapid/pressReleaseAction.do?reference=IP/10/1071

Note 2. A special thanks goes to the Brussels-based think tank Centre for European Studies to provide me the opportunity for the research on euroscepticism. See also Florian Hartleb: A thorn in the side of European elites. The new Euroscepticism, Centre for European Studies, Brussels 2011.

Note 3. But, 'It is the status quo that if left as it is, will allow euro scepticism to grow.' Retrieved 15 March, 2009 , from http://euobserver.com/883/27286, accessed.

Note 4. Inaugural speech by Robin Matthews, head of the Libertas UK campaign; Retrieved from http://www.libertas.eu/united-kingdom, accessed March 2009. 